\title{
Antibiogram Profiling and Thermal Inactivation of Staphylococcus aureus and Escherichia coli Isolated from Milk of Dharan, Nepal
}

\author{
${ }^{a}$ Susmita Phattepuri, ${ }^{a}$ Prince Subba, ${ }^{a}$ Arjun Ghimire, ${ }^{a}$ Shiv Nandan Sah * \\ ${ }^{a}$ Department of Microbiology, Central Campus of Technology, Tribhuvan University, Dharan, Sunsari, Nepal \\ *Corresponding email: sahshivnandan96@gmail.com
}

\begin{abstract}
Milk is an excellent medium for the growth of many bacteria. The aim of this study was to determine antibiotic profiling and thermal inactivation of Staphylococcus aureus and Escherichia coli isolated from raw milk of Dharan. Total viable, total staphylococcal, and total coliform counts were carried out by conventional microbiological methods. Identification was done based on Gram's staining and biochemical tests. The antibiotic susceptibility test was carried out by the modified Kirby-Baur disc diffusion method. Thermal inactivation of the isolates was carried out by subjecting them to thermal treatment in a water bath. Total plate count ranged from $204 \times 10^{4} \mathrm{CFU} / \mathrm{mL}$ to $332 \times 10^{5}$ $\mathrm{CFU} / \mathrm{mL}$. Total staphylococcal and total coliform counts ranged from $14 \times 10^{5} \mathrm{CFU} / \mathrm{mL}$ to $8 \times 10^{6} \mathrm{CFU} / \mathrm{mL}$ and $11 \times 10^{4} \mathrm{CFU} / \mathrm{mL}$ to $3 \times 10^{6} \mathrm{CFU} / \mathrm{mL}$ respectively. S. aureus showed an increasing resistance patterns towards Ampicillin, Cefotixin, Carbenicillin and Cefotaxime. Ciprofloxacin, Erythromycin, Amikacin, Gentamycin, Azithromycin, and Chloramphenicol were found to be effective against $S$. aureus. All the $E$. coli isolates were resistant to Ampicillin and least resistant to Cefotixin. Chloramphenicol, Amikacin, Azithromycin, and Nalidixic acid were found highly effective in E. coli. The D-values for $S$. aureus at $56^{\circ} \mathrm{C}$, $58^{\circ} \mathrm{C}$ and $60^{\circ} \mathrm{C}$ were $1.36 \mathrm{~min}, 1.19 \mathrm{~min}$, and $1.09 \mathrm{~min}$ respectively. The Z-value was $14.92^{\circ} \mathrm{C}$. While $\mathrm{D}$-values were obtained as $0.98 \mathrm{~min}, 0.75$ $\mathrm{min}$, and $0.57 \mathrm{~min}$ for $\mathrm{E}$. coli at $56^{\circ} \mathrm{C}, 58^{\circ} \mathrm{C}$ and $60^{\circ} \mathrm{C}$ respectively, and Z-value was $9.75^{\circ}$ C. Hence, S. aureus was found to be more heat resistant than E. coli.
\end{abstract}

\author{
Article Info \\ Article history: \\ Received date: 24 May 2020 \\ Accepted date: 20 October 2020
}

Keywords:

Antibiogram profiling

Thermal Inactivation

Escherichia coli

Staphylococcus aureus

D-value

Z-value

\section{Introduction}

Milk is defined to be the lacteal secretion, practically free from colostrums, obtained by the complete milking of one or more healthy cows, five days after and 15 days before parturition, which contains not less than 8.5 percent milk solids-not-fat and not less than 3.5 percent milk fat (USPHS, 1965; Itzerott, 1960).Milk is a complete food, containing proteins, fats, carbohydrates, vitamins, and mineral salts. Milk has been referred to as the "most nearly perfect" food containing proteins, carbohydrates, fats, minerals, vitamins, and water as chief constituents (Park et al., 2007). Milk is also an excellent medium for the growth of many bacteria (Pelczar et al., 2013).

When milk is drawn from the udder of a healthy animal, milk contains organisms from the teat canal. They are mechanically flushed out during milking. Milking under hygienic conditions with strict attention to sanitary practices will result in a product with low bacterial content and good keeping quality (Pelczar et al., 2013). Milk and milk products are highly susceptible to microbial contamination because their composition provides a favourable medium for the growth of a wide variety of microorganisms (De Buyser et al., 2001; Van Kessel et al., 2004). Pathogens like E. coli, Staphylococcus spp., Lactobacillus spp., Bacillus spp., Streptococcus spp., Listeria monocytogenes, etc are commonly found in milk (Maniruzzaman et al., 2010). Among them, E. coli and Staphylococcus aureus are the most common contaminants. These microorganisms may gain access to milk or the products of the milk through the interior 
of the udder, exterior of the cow's body, atmosphere, utensils, milker or handler, and various ingredients added to dairy products (Eckles et al., 2000). S. aureus has been known for decades as a bacterium that contaminated milk and causes food poisoning (Farzana et al., 2004). Presence of staphylococcal enterotoxins can cause gastroenteritis. Exotoxins producing $S$. aureus are the most dangerous and harmful for human health (Thaker et al., 2013).

Although, recognized as an opportunistic infective agent in wound, (Halpin-Dohnalek and Martha, 1989; Jablonski and Bohach, 1997), S. aureus infection now poses even more challenges associated with the emergence and dissemination of multiple antibiotic resistant $S$. aureus strains. Illness through $S$. aureus range from minor skin infection such as pimples, boils, impetigo to life-threatening disease such as pneumonia, meningitis, endocarditis, and septicaemia (Soomro et al., 2003; Masud et al., 1988).

E. coli is often used as a marker organism. Recovery of $E$. coli is used as a reliable indicator of faecal contamination and indicates the possible presence of enteropathogenic microorganisms which constitute a public health hazard (Bali et al., 2013). Generally, most of the E. coli bacteria are harmless, but some are known to be pathogenic bacteria, causing severe intestinal and extra-intestinal diseases in man (Kaper et al., 2004). Clinical infections caused by $E$. coli include urinary tract infection, septic infections of a wound, diarrhoeas, dysentery, septicaemia, pneumonia, neonatal meningitis, and abscesses in a variety of organs (Chakraborty, 2003).

Therefore, this study aimed to determine the sensitivity of $S$. aureus and E. coli isolated from raw milk against several antibiotics and to study heat resistance of $S$. aureus and $E$. coli isolated from raw milk samples.

\section{Materials and Methods}

\subsection{Sample collection}

Altogether 10 milk samples were collected aseptically in a dry and clean plastic container by random sampling method from households of Dharan, Sunsari, Nepal, and transported to the microbiology laboratory of Central Campus of Technology, Hattisar, Tribhuvan University, Dharan, for the laboratory work from May to August 2016. Samples were processed immediately as soon as possible (within 30 mins) otherwise preserved at $4^{\circ} \mathrm{C}$.

\subsection{Isolation and identification of S. aureus and $\mathbf{E}$. coli}

S. aureus and E. coli were isolated on Mannitol salt agar (MSA) and Eosin methylene blue (EMB) agar plates respectively by spread plate techniques followed by serial dilution of the milk samples. Then the inoculated plates were incubated at $37^{\circ} \mathrm{C}$ for 48 hours. Moreover, total plate count $(\mathrm{CFU} / \mathrm{mL})$ was also carried out on plate count agar by pour plate technique (Aneja, 2003).

Golden yellow and orange colonies developed on MSA were selected and streaked on Nutrient agar (NA) where $S$. aureus gave large, round, smooth, raised, shiny, and opaque colonies. For E. coli, green metallic sheen colonies developed on EMB were subcultured on Nutrient agar and incubated at $37^{\circ} \mathrm{C}$ for 24 hours.

Identification and confirmation of presumptive $S$. aureus and E. coli were done by using standard microbiological techniques as described in Bergey's Manual. After Gram's staining, biochemical tests were carried out for the identification of the organisms. The antibiotic susceptibility test of the isolates was done by the modified Kirby-Baur disc diffusion method as recommended by Clinical and Laboratory Standards Institute by using MuellenHinton agar (MHA) (CLSI, 2014). Antibiotics namely, Ampicillin, Azithromycin, Ciprofloxacin, Erythromycin, Gentamycin, Ceftriaxone, Cefotaxime, Amikacin, Carbenicillin, Nalidixic acid, and Chloramphenicol were used for Antibiotic Susceptibility Test.

\subsection{Thermal Treatment}

Identified bacteria (S. aureus and E. coli) were sub-cultured into Nutrient agar. The colonies were inoculated in Nutrient broth (NB) and incubated at $37^{\circ} \mathrm{C}$ for $24 \mathrm{~h}$ and finally stored in at refrigerator as a pure culture. For thermal inactivation; Isolated $S$. aureus and E. coli were inoculated in NB and incubated at $37^{\circ} \mathrm{C}$ for $4 \mathrm{~h}$ to obtain the turbidity of 0.5 McFarland standards. Then $10 \mathrm{~mL}$ of sterile milk was taken in sterile test tubes. $1 \mathrm{~mL}$ of each bacterial suspension was poured into the test tubes and subjected to thermal treatment in a water bath. Each heat treatment was conducted triplicate for each of the time/temperature combinations.

To calculate D-value, bacteria containing milk were heated at a certain temperature for five different 
times; namely 1 min, 2 min, 3 min, 4 min, and 5 min. Similarly, to calculate Z-value, thermal treatment was conducted at three different temperatures; namely $56^{\circ}$ $\mathrm{C}, 58^{\circ} \mathrm{C}$ and $60^{\circ} \mathrm{C}$.

After heat treatment, test tubes were removed and placed in the ice-water bath. Isolation and enumeration of $S$. aureus and $E$. coli were performed by using spread plate techniques after serial dilution on MSA and EMB agar respectively.

\subsection{Calculation of D and Z-values}

For the calculation of the D-value, the average of the log number of bacteria was plotted against the treatment time at each temperature. The average slope and standard error (SE) of the resultant curves were obtained using linear regression analysis (Excel), and used to calculate D-values for each temperature treatment using the equation 1 .

$$
\mathrm{D}=-1 / \text { slope }
$$

Z-value was calculated from slope of an individual curve of a plot of D-values against temperature by linear regression of the slopes of the plots. The regression coefficient $\left(\mathrm{R}^{2}\right)$ of the slope of the curve was used to check the goodness of fit. S. aureus and E. coli used in this study were isolated from raw milk.

\section{Results and Discussion}

Analysis of results showed that out of 10 milk samples, S. aureus was found in 2 (20\%) samples and E. coli was present in $6(60 \%)$ milk samples. Total plate count of raw milk ranged from $204 \times 10^{4}$ $\mathrm{CFU} / \mathrm{mL}$ to $332 \times 10^{5} \mathrm{CFU} / \mathrm{mL}$. The total staphylococcal count ranged from $14 \times 10^{5} \mathrm{CFU} / \mathrm{mL}$ to $8 \times 10^{6} \mathrm{CFU} / \mathrm{mL}$ whereas total coliform count ranged from $11 \times 10^{4} \mathrm{CFU} / \mathrm{mL}$ to $3 \times 10^{6} \mathrm{CFU} / \mathrm{mL}$.

Two isolates of $S$. aureus and six isolates of $E$. coli were subjected to antibiotic sensitivity tests. 11 antimicrobial agents belonging to different antibiotic classes were used. The most resistant drug was Ampicillin against all the isolates of $E$. coli and $S$. aureus. Also, all isolates of $E$. coli were found to be more or less susceptible to the rest of the antibiotics. Similarly, all isolates of $S$. aureus were found to be resistant to Cefotixin, Carbenicillin, and Cefotaxime and were more or less susceptible to remaining antibiotics (Table 6).
Table 1: Biochemical characterization of S. aureus

\begin{tabular}{lc}
\hline \multicolumn{1}{c}{ Biochemical test } & Reaction \\
\hline Catalase & + \\
Coagulase & + \\
Indole & - \\
Methyl red & + \\
Voges-proskauer & \pm \\
Citrate utilization & - \\
Nitrate reduction & + \\
Gelatin liquefaction & + \\
\hline
\end{tabular}

Table 2: Biochemical characterization of E. coli

\begin{tabular}{lc}
\hline \multicolumn{1}{c}{ Biochemical test } & Reaction \\
\hline Catalase & + \\
Indole & + \\
Methyl red & + \\
Voges-proskauer & - \\
Citrate utilization & - \\
Nitrate reduction & + \\
Gelatin liquefaction & - \\
SIM & + \\
Urease activity & - \\
TSI & Acid/acid \\
\hline
\end{tabular}

Table 3: Total Viable Bacterial Count.

\begin{tabular}{cl}
\hline Samples no. & $\begin{array}{l}\text { No. of cells/ ml } \\
\text { (CFU/ mL) }\end{array}$ \\
\hline 1 & $214 \times 10^{5}$ \\
2 & $184 \times 10^{5}$ \\
3 & $204 \times 10^{4}$ \\
4 & $148 \times 10^{5}$ \\
5 & $220 \times 10^{5}$ \\
6 & $160 \times 10^{5}$ \\
7 & $28 \times 10^{6}$ \\
8 & $248 \times 10^{5}$ \\
9 & $17 \times 10^{6}$ \\
10 & $332 \times 10^{5}$ \\
\hline
\end{tabular}

Table 4: Total Staphylococcal Count

\begin{tabular}{cc}
\hline Sample No & $\begin{array}{c}\text { Number of cells/ml } \\
\text { (CFU/mL) }\end{array}$ \\
\hline 2 & $14 \times 10^{5}$ \\
10 & $8 \times 10^{6}$ \\
\hline
\end{tabular}

Table 5: Total Coliform Count

\begin{tabular}{cc}
\hline Sample No & $\begin{array}{c}\text { Number of cells/ml } \\
\text { (CFU/mL) }\end{array}$ \\
\hline 5 & $3 \times 10^{6}$ \\
6 & $5 \times 10^{5}$ \\
7 & $8 \times 10^{5}$ \\
8 & $7 \times 10^{5}$ \\
9 & $11 \times 10^{4}$ \\
10 & $12 \times 10^{5}$ \\
\hline
\end{tabular}


Table 6: Antibiotic Susceptibilities of $S$. aureus, and E. coli

\begin{tabular}{lrrrrrr}
\hline Antibiotics & \multicolumn{3}{c}{ S. aureus(n=2) } & \multicolumn{4}{c}{ E. coli (n=6) } \\
& (S) \% (I) \% & (R) \% & (S) \% & (I) \% & (R) \% \\
\hline Ampicillin & - & - & 100 & - & - & 100 \\
Ciprofloxacin & 100 & - & - & 3.3 & 66.6 & - \\
Erythromycin & 100 & - & - & 6.6 & 0.5 & 33.3 \\
Gentamycin & 50 & 50 & - & 6.6 & 33.3 & - \\
Azithromycin & - & 100 & - & 3.3 & 16.6 & - \\
Chloramphenicol & - & 100 & - & 100 & - & - \\
Nalidixic Acid & - & 50 & 50 & 83.3 & 16.6 & - \\
Cefotixin & - & - & 100 & 33.3 & 0.5 & 16.6 \\
Carbenicillin & - & - & 100 & - & 83.3 & 16.6 \\
Amikacin & 100 & - & - & 100 & - & - \\
Cefotaxime & - & - & 100 & 66.6 & 33.3 & - \\
\hline
\end{tabular}

The results obtained for the $\log \mathrm{D}$-values at three different temperatures and $\mathrm{Z}$-value are presented in Table 7. The thermal inactivation reactions followed first-order kinetics and goodness of fit $\left(\mathrm{R}^{2}\right)$ of 0.92 to 0.99 were obtained.

Table 7: $\quad$ D and Z-value of S. aureus and E. coli

\begin{tabular}{cccccc}
\hline $\begin{array}{c}\text { Organi } \\
\text { sms }\end{array}$ & $\begin{array}{c}\text { Temp. } \\
\left({ }^{\circ} \mathbf{C}\right)\end{array}$ & $\begin{array}{c}\mathbf{D}- \\
\text { value( } \\
\text { min) }\end{array}$ & $\mathbf{R}^{2} \mathbf{D}$ & $\begin{array}{c}\mathbf{Z}- \\
\text { value } \\
\left({ }^{\circ} \mathbf{C}\right)\end{array}$ & $\mathbf{R}^{2} \mathbf{z}$ \\
\hline S. & 56 & 1.36 & 0.928 & & \\
aureus & 58 & 1.19 & 0.967 & 14.92 & 0.978 \\
& 60 & 1.09 & 0.945 & & \\
\hline \multirow{3}{*}{ E. coli } & 56 & 0.98 & 0.951 & & \\
& 58 & 0.75 & 0.984 & 9.75 & 0.995 \\
& 60 & 0.57 & 0.992 & & \\
\hline
\end{tabular}

Note: $R^{2}{ }_{D}=R^{2}$ for $D$-value, $R^{2} Z^{=} R^{2}$ for $Z$-value.

In this study, the overall isolation rate of $S$. aureus in milk was $20 \%$ which seems to be similar to the findings like $17.39 \%$ by Tambekar and Bhutda (2010), $18.18 \%$ by Ekici (2004), and $18.80 \%$ by Santana (2010), and 20\% by Singh and Prakash (2008). Besides, the Contamination rate of E. coli in milk samples was found to be $60 \%$ which is similar to the finding like 57\% by Adesiyun (1994) and Soomro (2002).

Antimicrobial resistance has been recognized as an emerging worldwide problem in human medicine (Cohen, 2000) both in developed and developing countries. The susceptibility test results of $S$. aureus in the study showed $100 \%$ resistance to Ampicillin. Alian et al., (2012) also reported that resistance to Ampicillin was the most common finding (54.3\%). Moreover, this study showed resistance of $S$. aureus to Cefotixin, Carbenicillin, and Cefotaxime (100\%), and Nalidixic acid (50\%). However, S. aureus was found to be intermediately sensitive towards Chloramphenicol (100\%) and Gentamycin (50\%) which is by the findings of Mekuria et al., (2013) who reported $45.2 \%$ of $S$. aureus isolates were susceptible to Chloramphenicol and $38.1 \%$ were susceptible to gentamycin.

Antibiotic resistance in E. coli is of particular concern because it is the most common cause of urinary tract infections, bacteraemia (Salvadori et al., 2004) as well as a cause of diarrhea (Kaper et al., 2004). In this study, resistance was observed most often to Ampicillin (100\%) which is in agreement with the result of Aly et al., (2012) in which 95\% of E. coli isolates showed Ampicillin resistance. Similarly, Rasheed (2014) also recorded a high level of Ampicillin resistance among isolates of $E$. coli. About $33.3 \%$ of E. coli isolates were found resistant to erythromycin followed by Cefotixin and Carbenicillin (both 16.6\%).

The D-values found in this study are not in general agreement with the data available in the literature. Furthermore, differences in heat resistance have been described different species of the same genus, and among different strains of the same species. Intraspecies variation in resistance has been studied in several microorganisms, including Escherichia coli, Salmonella enterica, Aeromonas hydrophila, and Staphylococcus aureus, among others (Cebrian et al., 2007; Sherry et al., 2004). A representative example is Salmonella enterica serovar Senftenberg strain 775W, which shows $\mathrm{D}_{\mathrm{T}}$ values 10 times higher than other strains of the same species ( $\mathrm{Ng}$ et al., 1969; Mañas et al., 2001). Many studies have been published on this topic, and some interesting observations have been reported: wild strains, for instance, are frequently more heat resistant than laboratory strains (Humphrey et al., 1995).The reasons behind this behavior are not always known, and admittedly the final events leading to bacterial cell inactivation by heat are not fully clear. Heat affects diverse cellular structures and functions to a different degree, and those structures are interlinked. This complexity leads to the presence of sub lethally damaged cells with a variety of injuries, which will only be able to recover and resume growth under appropriate environmental conditions. Also, the survival or inactivation of vegetative bacteria exposed to thermal treatments is influenced by many factors, such as growth conditions (temperature, time, composition of the growth medium), previous exposure to stresses, and physicochemical characteristics of the treatment 
medium and environmental conditions after the treatment. The influence of these factors may be of great magnitude (Cebrián et al., 2017).

For example, Ugborogho and Ingham (1994) reported $\mathrm{D}_{56}$ values of 10.2 min for $S$. aureus ATCC 13565 and $13.2 \mathrm{~min}$ for $S$. aureus ATCC 14458. Kennedy (2004) also reported D-value at $56^{\circ} \mathrm{C}$ in the same range (13-21.7 $\mathrm{min})$. In contrast to it, the present study revealed that the $\mathrm{D}_{56}$ value was $1.36 \mathrm{~min}$. In reference data, $\mathrm{D}_{60}$ values ranged from 4.8-6.5 min but the $\mathrm{D}_{60}$ value obtained was 1.09 min. Similarly, the $\mathrm{D}_{58}$ value was also small (1.19 min) in this study than the reference data. In reference data Z-values ranged from 7.7 to $8^{\circ} \mathrm{C}$ but in this study, Z-value was $14.92^{\circ} \mathrm{C}$.

According to Holland and Dahlberg (1940), Pereira (2007), and Read (1961), E. coli was found to be considerably more heat resistant than the strain used in this study. Pereira reported D-value was 10.9 min at $55^{\circ} \mathrm{C}$ while the $\mathrm{D}_{56}$ value was $0.98 \mathrm{~min}$ in this study. In this study, the $\mathrm{D}_{58}$ value for $E$. coli was 0.75 min. However, in the study of Read, Schwartz, and Litsky, the $\mathrm{D}_{57}$ value was $1.3 \mathrm{~min}$. In this study, the $\mathrm{D}_{60}$ value for $E$. coli from milk sample was $0.57 \mathrm{~min}$ while Holland and Dahlberg reported that the $\mathrm{D}_{60}$ value for E. coli was $0.8 \mathrm{~min}$. Similarly, this study showed 9.75 for the Z-value of E. coli whereas that of reported by Holland and Dahlberg was $9.5^{\circ} \mathrm{C}$.

The range of heat resistance of vegetative bacterial cells is also wide. It is generally assumed that Grampositive cells are more resistant than Gram-negative cells (Jay, 1992) and those coccoid cells are more resistant than bacillary cells (Olson and Nottingham, 1980). Some genera are quite heat sensitive, for example, Aeromonas and Campylobacter (Sagarzazu, et al., 2010), whereas others are thoroughly heat resistant, such as Enterococcus (Sörqvist, 2003).

This study provides not only very important information on the antibiotic resistance pattern of $S$. aureus and $E$. coli but also thermal inactivation values of $S$. aureus and E. coli. However, the data generated strongly suggest that $S$. aureus is more heat resistant than E. coli.

\section{Conclusion}

In this study, raw milk collected from local areas of Dharan was found to be contaminated with $S$. aureus and E. coli. The milk isolates such as $S$. aureus was found to be MDR while E. coli showed gaining antibiotic-resistant. This study provides much-needed data on D-value and Z-value regarding both bacteria among which $S$. aureus is more heat resistant than $E$. coli. This study also suggests the need for further study on thermal inactivation of $S$. aureus.

\section{Acknowledgment}

We would like to express our sincere gratitude to the Department of Microbiology, Central Campus of Technology, Tribhuvan University, Dharan, for providing laboratory facilities that are required for smooth and efficient passage of work required for the completion of the project.

\section{Conflicts of Interest}

The authors declare that there is no conflict of interest with this publication.

\section{Funding}

This research received no external funding.

\section{References}

Adesiyun, A. A. (1994). Bacteriological quality and associated public health risk of pre-processed bovine milk in Trinidad. International Journal of Food Microbiology, 21(3), 253-261.

Alian, F., Rahimi, E., Shakerian, A., Momtaz, H., Riahi, M., \& Momeni, M. (2012). Antimicrobial resistance of Staphylococcus aureus isolated from bovine, sheep and goat raw milk. Global Veterinaria, 8(2), 111-114.

Aly, M. E., Essam, T. M., \& Amin, M. A. (2012). Antibiotic resistance profile of $E$. coli strains isolated from clinical specimens and food samples in Egypt. Int J Microbiol Res, 3(3), 176-182.

Amundson, D., Lindholm, C., Goyal, S. M., \& Robinson, R. A. (1988). Microbial pollution of well water in southeastern Minnesota. Journal of Environmental Science \& Health Part A, 23(5), 453-468.

Aneja, K. R. (2007). Experiments in microbiology, plant pathology and biotechnology. New Age International.

Bali, O. S., Lajnef, R., Felfoul, I., Attia, H., \& Ayadi, M. A. (2013). Detection of Escherichia coli in unpasteurized raw milk. International Journal of Agriculture and Food Science, 3(2), 53-55.

Cebrián, G., Condón, S., \& Mañas, P. (2017). Physiology of the inactivation of vegetative bacteria by thermal treatments: mode of action, 
influence of environmental factors and inactivation kinetics. Foods, 6(12), 107.

Cebrián, G., Sagarzazu, N., Pagán, R., Condón, S., \& Mañas, P. (2007). Heat and pulsed electric field resistance of pigmented and non-pigmented enterotoxigenic strains of Staphylococcus aureus in exponential and stationary phase of growth. International journal of food microbiology, 118(3), 304-311.

Chakraborty, P. (2005). A textbook of microbiology. New Central Book Agency.

CLSI. (2014). Performance standards for antimicrobial susceptibility testing: twenty second informational supplement 33. CLSI document M100-S20, Wayne, PA.

Cohen, M. L. (2000). Changing patterns of infectious disease. Nature, 406, 762-767.

De Buyser, M. L., Dufour, B., Maire, M., \& Lafarge, V. (2001). Implication of milk and milk products in food-borne diseases in France and in different industrialised countries. International journal of food microbiology, 67(1-2), 1-17.

Eckles, C. H., Combs, W. B., \& Macy, H. (1951). Milk and Milk Products, 4th edition, Tata McGraw-Hill Publishing Company Ltd, New Delhi.

Ekici, K., Bozkurt, H., \& Isleyici, O. (2004). Isolation of some pathogens from raw milk of different milch animals. Pakistan Journal of Nutrition, 3(3), 161-162.

Farzana, K., Shah, S. N. H., \& Jabeen, F. (2004). Antibiotic resistance pattern against various isolates of Staphylococcus aureus from raw milk samples. Journal of Research (Science), 15(2), 145-51.

Halpin-Dohnalek, M. I., \& Marth, E. H. (1989). Growth of Staphylococcus aureus in milks and creams with various amounts of milk fat. Journal of food protection, 52(8), 540-543.

Holland, R. F., \& Dahlberg, A. C. (1940). The effect of the time and temperature of pasteurization upon some of the properties and constituents of milk. New York State Agric. Experim. Station, Geneva, N. Y. Technical Bull. 254, pp.55.

Humphrey, T. J., Slater, E., McAlpine, K., Rowbury, R. J., \& Gilbert, R. J. (1995). Salmonella enteritidis phage type 4 isolates more tolerant of heat, acid, or hydrogen peroxide also survive longer on surfaces. Applied and Environmental Microbiology, 61(8), 3161-3164.

Itzerott, G. (1960). Notes on milk and indigenous dairy products in Pakistan. OV.
Jablonski, L. M. \& Bohach G. A., (1997). Staphylococcus aureus. Food microbiology, fundamentals and frontiers, 353-375.

Jay, J. M., Loessner, M. J., \& Golden, D. A. (2005). Modern food microbiology. Springer Science \& Business Media.

Kaper, J. B., Nataro, J. P., \&. Mobley, H. L. T., (2004). Pathogenic Escherichia coli. Nature Reviews Microbiology, 2, 123-140.

Mañas, P., Pagán, R., Sala, F. J., \& Condón, S. (2001). Low molecular weight milk whey components protect Salmonella Senftenberg 775W against heat by a mechanism involving divalent cations. Journal of applied microbiology, 91(5), 871-877.

Maniruzzaman, M., Khan, M. F. R., Amin, M. M., Paul, A. K., \& Islam, M. (2010). Isolation and identification of bacterial flora from milk of apparently healthy buffalo-cows. Int J BioRes, 1(3), 13-6.

Masud, T., Athar, I. H., Chishti, M. A., \& Shah, M. A. (1988). Microbiological studies on indigenous dahi with special reference to public health [Pakistan]. Journal of Animal Health and Production, 8, 8-13.

Mekuria, A., Asrat, D., Woldeamanuel, Y., \& Tefera, G. (2013). Identification and antimicrobial susceptibility of Staphylococcus aureus isolated from milk samples of dairy cows and nasal swabs of farm workers in selected dairy farms around Addis Ababa, Ethiopia. Afr J Microbiol Res, 7(27), 3501-3510.

Ng, H., Bayne, H. G., \& Garibaldi, J. A. (1969). Heat resistance of Salmonella: the uniqueness of Salmonella Senftenberg 775W. Applied microbiology, 17(1), 78-82.

Olson, J. C., \& Nottingham, P. M. (1980). Temperature in microbial ecology of foods volume 1: factors affecting life and death of microorganisms. International Commission on Microbiological specifications for foods.

Park, Y. W., Juárez, M., Ramos, M., \& Haenlein, G. F. W. (2007). Physico-chemical characteristics of goat and sheep milk. Small ruminant research, 68(1-2), 88-113.

Pelczar, M. J. J. R., \& Reid, R. D. (2013). Microbiology 5th edition, Tata McGraw-Hill Publishing Company Ltd, New York,

Pereira, R., Martins, J., Mateus, C., Teixeira, J. A., \& Vicente, A. A. (2007). Death kinetics of Escherichia coli in goat milk and Bacillus licheniformis in cloudberry jam treated by ohmic heating. Chemical Papers, 61(2), 121-126. 
Rasheed, M. U., Thajuddin, N., Ahamed, P., Teklemariam, Z., \& Jamil, K. (2014). Antimicrobial drug resistance in strains of Escherichia coli isolated from food sources. Revista do Instituto de Medicina Tropical de São Paulo, 56(4), 341-346.

Read, R. B., Schwartz, C., \& Litsky, W. (1961). Studies on the thermal destruction of Escherichia coli in milk and milk products. Applied microbiology, 9(5), 415-418.

Sagarzazu, N., Cebrián, G., Pagán, R., Condón, S., \& Mañas, P. (2010). Resistance of Campylobacter jejuni to heat and to pulsed electric fields. Innovative Food Science \& Emerging Technologies, 11(2), 283-289.

Salvadori, M., Coleman, B. L., Louie, M., McEwen, S., \& McGeer, A. (2004). Consumption of antimicrobial-resistant Escherichia coli contaminated well water: human health impact. PSI Clin Res, 1, 6-25.

Santana, E. H. W., Cunha, M. D. L. R. D. S. D., Oliveira, T. C. R. M. D., Moraes, L. B., AragonAlegro, L. C., \& Beloti, V. (2010). Assessment of the risk of raw milk consumption related to staphylococcal food poisoning. Ciência Animal Brasileira, 643-652.

Sherry, A. E., Patterson, M. F., \& Madden, R. H. (2004). Comparison of 40 Salmonella enterica serovars injured by thermal, high pressure and irradiation stress. Journal of Applied Microbiology, 96(4), 887-893.

Singh, P., \& Prakash, A. (2008). Isolation of Escherichia coli, Staphylococcus aureus and Listeria monocytogenes from milk products sold under market conditions at Agra region. Acta agriculturae Slovenica, 92(1), 83-88.
Soomro, A. H., Arain, M. A., Khaskheli, M., \& Bhutto, B. (2002). Isolation of Escherichia coli from raw milk and milk products in relation to public health sold under market conditions at Tandojam. Pakistan Journal of Nutrition, 1(3), 151-152.

Soomro, A. H., Arain, M. A., Khashkeli, M., Bhutto, B., \& Memon, A. Q. (2003). Isolation of Staphylococcus aureus from milk products sold at sweet meat shops of Hyderabad. On Line Journal of Biological Sciences, 3(1), 91-94.

Sörqvist, S. (2003). Heat Resistance in Liquids of Enterococcus spp., Listeria spp., Escherichia coli, Yersinia enterocolitica, Salmonella spp. and Campylobacter spp. Acta Veterinaria Scandinavica, 44(1), 1-19.

Tambekar, D. H., \& Bhutda, S. A. (2010). Prevalence of bacterial pathogens in pedha (a milk product) sold in Amravati (India). International journal of dairy science, 5(3), 173-176.

Thaker, H. C., Brahmbhatt, M. N., Nayak, J. B., \& Thaker, H. C. (2013). Isolation and identification of Staphylococcus aureus from milk and milk products and their drug resistance patterns in Anand, Gujarat. Veterinary World, 6(1), 10-13.

UUgborogho, T. O., \& Ingham, S. C. (1994). Increased D-values of Staphylococcus aureus resulting from anaerobic heating and enumeration of survivors. Food microbiology, 11(4), 275-280.

USPHS. (1965). Grade A pasteurized milk ordinance: 1965 recommendations of the United States Public Health Service, 13th edition, U.S. Government Print, Washington.

Van Kessel, J. S., Karns, J. S., Gorski, L., McCluskey, B. J., \& Perdue, M. L. (2004). Prevalence of Salmonellae, Listeria monocytogenes, and fecal coliforms in bulk tank milk on US dairies. Journal of Dairy Science, 87(9), 2822-2830.

How to cite: Phattepuri, S., Subba, P., Ghimire, A., \& Sah, S. N. (2020). Antibiogram Profiling and Thermal Inactivation of Staphylococcus aureus and Escherichia coli Isolated from Milk of Dharan, Nepal. Himalayan Journal of Science and Technology, 3-4, 81-87. 